Ks. Henryk DYBSKI

(Łomża, WSD)

\title{
NAJSTARSZE ŹRÓDŁA O ŻYCIU IZAAKA SYRYJCZYKA BISKUPA NINIWY
}

$\mathrm{Na}$ początku naszych rozważań, dotyczących Izaaka Syryjczyka, należy stwierdzić, że informacje biograficzne czerpiemy o nim przede wszystkim z dwóch źródeł syryjskich. Pierwszym z nich jest Księga czystości, napisana prawdopodobnie między 860 a 870 r. przez wschodniosyryjskiego historyka Iszodenaha, biskupa Basry, w której przedstawia on krótkie żywoty sławnych ascetów Kościoła perskiego (zwanego także asyryjskim lub wschodniosyryjskim); rozdział 124 tego dzieła poświęcony jest Izaakowi, sam zaś jego tytuł zachęca do bliższego zapoznania się z treścią: „O świętym Mar ${ }^{1}$ Izaaku, biskupie Niniwy, który zrzekł się biskupstwa i ułożył księgi o dyscyplinie życia pustelniczego". Drugim biograficznym źródłem jest zachodniosyryjskie świadectwo, którego autora, czas powstania i miejsce redakcji dokładnie nie znamy. Jednakże włoski uczony P. Bettiolo uważa, że powstało ono na początku $900 \mathrm{r}$. w środowisku związanym z klasztorem Rabban Szabur w Mezopotamii, gdzie Izaak spędził ostatnie lata swojego życia ${ }^{2}$. Trzecim natomiast jest dokument wschodniosyryjski, który wyszedł spod pióra nieznanego hagiografa w języku arabskim.

\section{1. Źródło wschodniosyryjskie Iszodenaha, biskupa Basry. Najpierw uwagę} skupimy na pozycji Iszodenaha, który wprowadził nas w niektóre wydarzenia mające miejsce w życiu Izaaka; są to dane, które mają wyjątkowe znaczenie dla

${ }^{1}$ Mar - jest to słowo syryjskie. W tłumaczeniu na język polski znaczy pan. Tytuł ten był używany na Wschodzie i przysługiwał ascetom znanym z świętości życia, jak również biskupom. Jeżeli występował bezpośrednio przed imieniem znaczył tyle, co święty; por. A.В. Муравьев, w: Мар Афрем Нисибинский (Прп. Ефрем Сирин), Юлианский цикл, Москва 2006, 13, przyрis 1 do Wstępu; С. Соболевский, Иже во святьх Омца намего Аввы Исаака Сирианина, „Слоба побвижнические”, Сергеев Посад 1911, издание репринтное: Москва 1993, III, przypis 1 do Wstępu.

2 Por. И. Алфеев, Духовный мир преподобного Исаака Сирина, Санкт-Петербург 2005 , 19; P. Bettiolo (ed.), Isacco di Ninive. Discorsi spirituali. Introduzione, traduzione e note, Bose 1990, 10. 
naszej wiedzy o biskupie Niniwy, zwłaszcza, że jeśli nie jest to najstarszy, to na pewno jeden z najważniejszych utworów, jakie się o nim zachowały. A oto, co pisze biskup Basry o Izaaku:

„Był on ustanowiony biskupem Niniwy ${ }^{3}$ przez katolikosa ${ }^{4}$ Mar Giwargisa (Jerzego) w klasztorze Beit Abé. Po pięciu miesiącach przebywania na urzędzie pasterza Niniwy, jako następca biskupa Mojżesza, zrezygnował z biskupstwa z przyczyny znanej Bogu i odszedł, by zamieszkać w górach. Katedra pozostawała nieobsadzona przez pewien czas, po czym jego następcą został błogosławiony Sabriszo, który także zrzekł się biskupstwa i żył jako pustelnik, gdy katolikosem był Henaniszo, a potem umarł w klasztorze Mar Szahina w kraju Kardu. Kiedy Izaak opuścił tron Niniwy, wszedł na górę Matut, położoną w regionie Beit Huzaje i tam zamieszkał w spokoju obok eremitów, znajdujących się w pobliżu; potem udał się do klasztoru Rabban Szabur. Był nadzwyczaj zaznajomiony z boskimi Pismami, i to aż do tego stopnia, że stracił wzrok z powodu czytania i ascezy. Głęboko przeniknął on boskie tajemnice i ułożył księgi o dyscyplinie życia pustelniczego. Wypowiedział też trzy zdania, które przez wielu nie były przyjęte. Oburzał się na niego m.in. Daniel Bar Tubanita, biskup Beit Garmai, z powodu głoszonych przez niego tych trzech twierdzeń. Gdy osiągnął sędziwy wiek, odszedł z tego doczesnego życia, a jego ciało złożono w klasztorze Szabur. Izaak urodził się w Beit Katraje i myślę, że wzbudzał on zazdrość wśród tych, którzy mieszkali w środkowej części (Mezopotamii) ${ }^{5}$, podobnie jak to było w przypadku Józefa Hazzaja, Jana z Apamei i Jana z Daljaty”.6.

Po bliższym zapoznaniu się z przytoczonym wyżej tekstem nasuwa się wniosek, że zawarta w nim treść posiada mało szczegółów o samym Izaaku i dlatego zasadniczo niewiele dowiadujemy się z niej, zarówno o nim samym, jak i jego twórczości literackiej. Zupełnie nieznane są lata jego dzieciństwa i młodości, choć skądinąd z dużą dokładnością da się określić czas życia i miejsca jego pobytu. Pomimo tak ubogiego materiału źródłowego, pragniemy podjąć próbę analizy, by wydobyć jak najwięcej faktów z życia Izaaka i ułożyć je w pewną logiczną i uporządkowaną całość, wykorzystując również literaturę przedmiotu.

${ }^{3}$ Niniwa podlegała metropolicie miasta Erbil (Arbela). Obecnie Niniwa znajduje się na terytorium Iraku, por. Алфеев, Духовный мир преподобного Исаака Сирина, s. 21, przyріs 25; S. Rejak, Eschatologiczna nadzieja w pismach Izaaka Syryjczyka, Lublin 2003, 15, przypis 6.

${ }^{4}$ Termin katolikos pochodzi z języka greckiego i znaczy uniwersalny, powszechny. Słowo to zostało przejęte przez Syryjczyków, którzy stosowali je od V wieku jako tytuł biskupa Seleucji Ktezyfonu, miasta leżącego w południowej Mezopotamii i będącego wówczas stolicą imperium perskiego; por. Bettiolo (ed.), Isacco di Ninive, s. 41, przypis 4; Rejak, Eschatologiczna nadzieja, s. 15 , przypis 7 .

5 Jest to środkowy obszar Mezopotamii, leżący między Tygrysem a Eufratem; por. Алфеeв, w: Духовньй мир преподобного Исаака Сирина, s. 20, przypis 20; Rejak, Eschatologiczna nadzieja, s. 15 , przypis 9 .

6 Por. J.B. Chabot, Le livre de la chasteté, composé par Jésusdenah, évêque de Basrah, „Mélanges d'Archéologie et d'Histoire” 16 (1896) 63-64 n (textus), 53-54 n (versio), wyd. 2: P. Bedjan, Liber fundatorum monasteriorum in regno Persarum et Arabum, Paris - Leipzig 1901, 508. 
Otóż z relacji historyka Iszodenaha dowiadujemy się, że Izaak urodził się w regionie Beit Katraje, który obejmował zachodnie wybrzeże Zatoki Perskiej wraz z przylegającymi do niej wyspami ${ }^{7}$. W przytoczonym fragmencie nie ma wzmianki nie tylko o konkretnej, ale nawet przybliżonej dacie przyjścia na świat Izaaka. Biskup Basry wymienia ponadto Izaaka wśród hierarchów Niniwy, co następnie potwierdza poprzez wyliczenie imion pasterzy tego miasta, a mianowicie Mojżesza, który piastował tę godność przed nim oraz jego następcy Sabriszo. Wiemy, że w latach $685-700$ katolikosem był Henaniszo ${ }^{8}$ i to właśnie podczas jego urzędowania biskup Sabriszo prowadził życie pustelnicze, po uprzedniej i dobrowolnej rezygnacji z tej funkcji, o czym zapewnia czytelnika historyk Iszodenah i w ten sposób uwiarygodnia swój przekaz o Izaaku.

Znana jest nam także postać Mar Giwargisa, o którym niektórzy autorzy zajmujący się jego biografią twierdzą, że był on katolikosem Kościoła perskiego w latach $661-680 / 681^{9}$. Podany czas sprawowania władzy patriarszej przez Giwargisa odgrywa tu bardzo ważną rolę, gdyż to on udzielił Izaakowi sakry biskupiej w klasztorze Beit Abé. Nic więc dziwnego, że uczeni poruszający to zagadnienie są zdania, iż Izaak został hierarchą między 660 a 680 r., powołując się przy tym na okres rządów jego konsekratora ${ }^{10}$. Należy podkreślić, że przedstawiony tu termin jest jednocześnie pierwszą i ostatnią pewną datą, którą można ustalić w życiorysie Izaaka na podstawie lektury 124 rozdziału Liber castitatis. Trzeba też dodać, że Iszodenah nie pisze o konkretnym roku wyboru Izaaka na katedrę Niniwy, lecz wskazuje jedynie na biskupa, który go konsekrował oraz na miejsce tego doniosłego aktu liturgicznego. Kontynuując refleksję nad analizowanym źródłem wschodniosyryjskim, warto odnotować krótki, bo zaledwie pięciomiesięczny pobyt Izaaka na katedrze Niniwy. Iszodenah i w tym przypadku jest nader oszczędny w słowach i nie podaje nawet

7 Obecnie część tego terytorium zajmuje państwo Katar; por. też Алфеeв, Духовньцй мир преподобного Исаака Сирина, s. 21, przypis; W. Hryniewicz, Nadzieja świętych - świadectwo sw. Izaaka Syryjczyka, w tegoż: Dramat nadziei zbawienia (Medytacje eschatologiczne), Warszawa 1996, 149; Rejak, Eschatologiczna nadzieja, s. 14 i 16.

${ }^{8}$ Por. Алфеев, Духовный мир преподобного Исаака Сирина, s. 20.

9 Por. Bettiolo (ed.), Isacco di Ninive, s. 11; В. Болотов, Из истории Церкви Сиро-Персидской. Христианское чтение, t. 207, сz. 1, Санкт-Петербург 1899, 1028 (Bołotow uważa, że Giwargis ,był ustanowiony biskupem pod koniec 660 r. lub na początku 661 r. [...] i umarł pod koniec 680 r., tzn. był patriarchą prawie 20 lat słonecznych"; Г. Флоробский, Византийские Oтцы V-VIII в8., Минск 2006, 234; В. Пигулевская, Культура сирийцев в середине века, Москва 1979, 219; Hryniewicz, Nadzieja świętych - świadectwo św. Izaaka Syryjczyka, s. 149; Rejak, Eschatologiczna nadzieja, s. 15, przypis 8.

${ }^{10}$ Por. Флоробский, Византийские Отць V-VIII в8., s. 234; A. Guillaumont, Syryjski mistyk Izaak z Niniwy, w tegoz: U źródet monastycyzmu chrześcijańskiego, tłum. S. Wirpszanka, t. 2, ŹM 38, Kraków 2006, 267; M. Nin, Główne kierunki duchowości monastycyzmu syryjskiego, tłum. A. Jankowski, w: Duchowość starożytnego monastycyzmu (Materiały z międzynarodowej sesji naukowej (Kraków - Tyniec, 16-19 XI 1994), Kraków 1995, 53; M. Starowieyski, Izaak, biskup Niniwy, SWPW 100. 
powodu tak szybkiej jego rezygnacji z zajmowanego stanowiska. Nawiązując do poprzedniego zdania, można przypuszczać, że Izaak, który tak bardzo cenił życie monastyczne, nie od razu, ale po wielu usilnych prośbach, zaakceptował propozycję Giwargisa. W biografii Iszodenaha o Izaaku z Beit Katraje interesujące jest i to, że po opuszczeniu swojej stolicy biskupiej, nie powrócił do ziemi ojczystej, do klasztoru Beit Abé, z którym - jak wiele na to wskazuje - był związany i gdzie prawdopodobnie rozpoczynał swe życie zakonne, ale pozostał w Mezopotamii, w regionie Beit Huzaje: był tam najpierw pustelnikiem wśród eremitów, a potem wstąpił do wspólnoty cenobitów Rabban Szabur.

Biskup Basry wystawia też Izaakowi dobrą opinię, chwaląc go za głęboką znajomość Pisma Świętego. Pragnienie Izaaka, by spotkać się z Bogiem w słowie zawartym w Biblii, było tak wielkie, ze w jej studiowaniu nie zachowywał potrzebnego umiaru, co z czasem odbiło się na jego zdrowiu. Potwierdza to Iszodenah w swoim świadectwie wyjaśniając, ze ta właśnie przyczyna oraz surowa asceza doprowadziły Izaaka aż do utraty wzroku. Wydaje się nam, iż zamiłowanie do czytania Ksiąg natchnionych, wyniósł nasz mnich-biskup, jeśli nie z domu rodzinnego, to zapewne z konwentu Beit Abé, a pogłębił je w Mezopotamii. Iszodenah podziwia także jego nadprzyrodzoną intuicję, która pozwoliła mu przenikać tajemnice Boże. Biskup Basry wskazuje przy tym na niezwykłą osobowość tego mnicha i mistyka, którego sława przekroczyła z czasem granice Mezopotamii, dzięki duchowej jakości jego dzieł, które stały się własnością zarówno chrześcijańskiego Wschodu, jak i Zachodu. Jeśli chodzi o twórczość literacką Izaaka, to autor Liber castitatis, ogranicza się jedynie do uwagi, że poruszona w niej tematyka, dotyczy życia pustelniczego. Nie podaje on jednak liczby ani tytułów pism, które wyszły spod pióra Izaaka, choć pisze o nich w liczbie mnogiej, co pozwala sądzić, że ma na myśli więcej niż jedno dzieło.

W Księdze czystości jest też mowa o trzech twierdzeniach głoszonych przez Izaaka, biskupa Niniwy, z którymi nie zgadzało się wielu mu współczesnych; jest to ważny problem, gdyż dotyczy nauczania Izaaka. W analizowanym dokumencie nie znajdujemy wyjaśnienia tej kwestii, a wśród osób zgorszonych jego wypowiedziami, imiennie wymieniony został jedynie Daniel Bar Tubanita, biskup Beit Garmai. W tej sprawie zabrał głos w rozprawie doktorskiej, poświęconej eschatologicznej nadziei u Izaaka, cytowany już S. Rejak. W jego przekonaniu, Izaak z Beit Katraje, miał tak żywe „,pragnienie niezniszczalności”, że stało się ono dla niego „źródłem twórczego niepokoju i inspiracją do poszukiwania odpowiedzi nawet za cenę niezrozumienia i odrzucenia przez współwyznawców"11. Uważa on ponadto, że Izaak stawiał sobie pytania o sens istnienia, o jego przemijalność i kategorycznie nie zgadzał się na swój niebyt, jak i swoich bliskich po przekroczeniu progu śmierci ${ }^{12}$. Podobny punkt widze-

11 Por. Rejak, Eschatologiczna nadzieja, s. 13-14.

2 Por. tamze, s. 13 
nia w tej materii głosili przed nim inni badacze tej tematyki, wśród których znajdują się znani syrolodzy i badacze życia oraz twórczości literackiej Izaaka: P. Bedjan i S. Brock. W ich przekonaniu konflikt spowodowany wypowiedziami Izaaka był natury teologicznej i dotyczył Gehenny ${ }^{13}$. Na podstawie opinii tych dwóch naukowców, można uznać, że przyczyną pewnych napięć Izaaka z otoczeniem były zbyt śmiałe jego poglądy eschatologiczne, które wykraczały poza oficjalne stanowisko przyjęte i głoszone przez Kościół.

Pod koniec 124 rozdziału Księgi czystości, Iszodenah oznajmia, że Izaak Syryjczyk zmarł jako starzec w klasztorze Rabban Szabur, który - według I. Alfiejewa i P. Bettiolo - znajdował się na górze Szusztar ${ }^{14}$.

2. Źródło zachodniosyryjskie nieznanego autora. Przechodząc do omówienia biografii Izaaka Syryjczyka na podstawie anonimowego świadectwa powstałego w środowisku zachodniosyryjskim, trzeba zaznaczyć, że wiele zdarzeń opisanych przez Iszodenaha odnajdujemy i tutaj. Niekiedy istnieje jednak między nimi pewna różnica polegająca na tym, że oprócz wspólnych elementów, w każdym z nich są umieszczone jeszcze dodatkowo nowe szczegóły, dzięki którym otrzymujemy pełniejszy obraz życia Izaaka z Beit Katraje.

Naszą refleksję rozpoczniemy od przedstawienia tych faktów zaczerpniętych z obu żywotów, które się ze sobą pokrywają. Uderzające jest to, że hagiografowie ci są całkowicie zgodni, m.in. co do miejsca przyjścia na świat, konsekracji biskupiej, życia monastycznego w Mezopotamii po rezygnacji z tego urzędu oraz śmierci Izaaka i jednomyślnie pomijają milczeniem czasowe ramy tych wydarzeń. Anonimowy pisarz kontynuując swoje opowiadanie podąża dalej jakby śladami Iszodenaha, gdyż wymienia imię tego samego katolikosa, który udzielił Izaakowi święceń biskupich, tak jak on podaje ten sam krótki okres jego urzędowania oraz nie wylicza konkretnych przyczyn, które wpłynęły na tak radykalną decyzję opuszczenia przez niego Niniwy. Przykładem potwierdzającym poprzednie zdanie może być formacja teologiczna Izaaka, który według utworu zachodniosyryjskiego „został wykształcony w kościelnych pismach i komentarzach”; głębokiej znajomości Pisma Świętego przez Izaaka wspominał także biskup Basry. Nieznany zaś redaktor powtarza ją w skróconej formie i zaraz dodaje, że Izaak korzystał także z opracowań wyjaśniających różne zagadnienia biblijne. Na ten temat wypowiedzieli się tacy znawcy przedmiotu, jak S. Brock ${ }^{15}$, A. Guillaumont ${ }^{16}$ czy

13 Por. tamże, s. 14, przypis 2.

${ }^{14}$ Рог. Алфеев, Духовньй мир преподобного Исаака Сирина, s. 23, przypis 39; Bettiolo (ed.), Isaco di Ninive, s. 18.

15 Por. С. Брок, Дверь в бесконечное пространство, w: И. Алфеев, Преподобный Исаак Сирин, „О божественньх тайнах и о буховной жизни”, Санкт-Петербург 2006, 13-14.

16 Por. Guillaumont, Syryjski mistyk Izaak z Niniwy, s. 276-280. 
W. Hryniewicz ${ }^{17}$, którzy są zdania, że Izaak czytał takich autorów chrześcijańskich, jak Bazyli Wielki, Pseudo-Makary, Ewagriusz z Pontu, Marek-Eremita, Dionizy Pseudo-Areopagita, Teodor z Mopsuestii, Efrem Syryjczyk czy Diodor z Tarsu. Można z tego wnioskować, że Izaak mógł korzystać z bogato zaopatrzonego księgozbioru bibliotecznego, który znajdował się prawdopodobnie w klasztorze Beit Abé, gdyż w omawianych tekstach nie ma mowy o innym cenobium. Nie oznacza to jednak, że w tym czasie była to jedyna wspólnota mnisza w regionie Beit Katraje. Nie jest też wykluczone, że lektura dzieł wyżej wspomnianych autorów oraz ewentualne kontakty osobiste z tą wspólnotą, wpłynęły w dużym stopniu na decyzję wyboru przez Izaaka życia monastycznego. Należy też zauważyć, iż tylko anonim podkreśla tak wyraźnie, że Izaak ,został mnichem [...] w swoim regionie”.

Jeśli chodzi o kolejność wydarzeń prezentowanych w źródle zachodniosyryjskim, to okazuje się, że Izaak dopiero po zdobyciu gruntownego wykształcenia wstąpił do wspólnoty cenobitów, a dopiero potem ,został ustanowiony biskupem Niniwy w klasztorze Beit Abé”. Zacytowany fragment zdaje się rozwiewać pojawiające się wątpliwości i jeszcze bardziej potwierdzać fakt, że Izaak był zakonnikiem tego właśnie konwentu, w którym dokonała się później jego konsekracja. Łatwo także dostrzec, że biskup Basry, podobnie jak nieznany autor, wskazuje na Beit Abé, jako na miejsce święceń biskupich Izaaka i jakby sugeruje, że tam właśnie Izaak rozpoczynał swoje życie zakonne, jakkolwiek historyk Iszodenah pisze wyraźnie o Izaaku, jako o mnichu, dopiero po jego rezygnacji z urzędu biskupiego.

Żywot zachodniosyryjski ukazuje ponadto Izaaka jako człowieka pochodzącego raczej z zamożnej rodziny, ponieważ było ją stać na opłacenie jego edukacji i dzięki temu został on ,nauczycielem w swoim regionie”. Warto też zauważyć, że anonim stwierdza, iż Izaak dostąpił godności biskupiej m.in. dlatego, że ,jednym z jego krewnych był Mar Gabriel z Kataru, który wykładał (Pisma) Kościoła" i był osobą znaną dla Mar Giwargisa.

Przy analizie obu omawianych źródeł ważne jest, by zwracać uwagę na wszystkie etapy życia Izaaka, czy nie znajdzie się wśród nich taki, który da się zamknąć w określonym czasie. O tym, że nie jest to łatwe zadanie, można się było przekonać badając świadectwo wschodniosyryjskie, w którym udało się uściślić zaledwie jedną pewną datę. Podobna sytuacja zachodzi także w przekazie zachodniosyryjskim. W nim bowiem zawarte są także dane, które naprowadzają na taki ślad, zwłaszcza wtedy, kiedy nieznany autor stwierdza, że „,katolikos Mar Giwargis (Jerzy) przybył do jego kraju” (Izaaka) i „Mar Izaak

17 Por. Hryniewicz, Nadzieja świętych - świadectwo św. Izaaka Syryjczyka, s. 149. O tym, że Izaak Syryjczyk znał wyżej wymienionych Ojców Kościoła i starożytnych pisarzy chrześcijańskich, dowiadujemy się przede wszystkim z jego mów, por. Sermo 14, 19-48, CSCO 554, Syr 224, 62-71; Sermo 39, 7-11, CSCO 554, Syr 224, 155-156. 
został ustanowiony biskupem Niniwy w klasztorze Beit Abé". Kluczowy fragment tego cytatu, prowadzący do osiągnięcia zamierzonego celu brzmi następująco: „gdy katolikos Mar Giwargis (Jerzy) przybył do jego kraju”. Istotny jest więc moment przybycia konsekratora Izaaka w region Beit Katraje. Odpowiedź na to pytanie znajdujemy w dokumentach Synodów Wschodnich, w których zamieszczona jest informacja o tym, że Mar Giwargis przyjechał w rodzinne strony Izaaka, w miesiącu ijar 57 r. panowania Arabów, czyli w maju $676 \mathrm{roku}^{18}$. W literaturze polskiej wypowiadali się na ten temat m.in. W. Hryniewicz ${ }^{19}$ i S. Rejak ${ }^{20}$, którzy zgodnie powtarzają wyżej wymieniony termin wizytacji tej prowincji przez Mar Giwargisa. W tym momencie możemy stwierdzić, że również i w utworze zachodniosyryjskim jest takie wydarzenie, które ma swoją konkretną datę. Pozwala to z kolei podać w przybliżeniu czas konsekracji Izaaka, która miała miejsce w 676 r. lub nieco później.

Spośród innych faktów zaczerpniętych z życia Izaaka, a obecnych w anonimowym świadectwie jest i taki, który opisuje chorobę jego oczu. Co prawda Iszodenah również wspomina o utracie wzroku przez Izaaka, ale bardziej rozwija ten wątek, wymieniając przyczyny, które spowodowały jego kalectwo. Nieznany zaś autor zachodniosyryjskiego świadectwa, wywodzący się z Mezopotamii, ze środowiska związanego prawdopodobnie z klasztorem Rabban Szabur, dzieląc się swoją wiedzą na ten temat podkreśla, że gdy Izaak utracił wzrok, wówczas ,bracia spisywali jego naukę i nazywali go drugim Dydymem, bo rzeczywiście był cichy, miły i pokorny, a jego słowo łagodne". Trudno w tych słowach nie dostrzec pochwały skierowanej pod adresem Izaaka. Redaktor tego tekstu nie ukrywa, jak wyjątkowym szacunkiem cieszył się Izaak wśród mnichów. Porównywali go oni z Dydymem Aleksandryjskim (ok. 312-398), który oślepł będąc jeszcze dzieckiem ${ }^{21}$ i podobnie, jak on, pod koniec swego życia, służył swoim doświadczeniem, dyktując klasztornym kopistom swoje idee ascetyczne. Wydaje się, że Izaak służył wówczas owocnie swoim współbraciom zarówno poprzez pogodną akceptację swojej nieuleczalnej choroby, jak i swoje pisma. Nieznany mezopotamski pisarz obok powyższych uwag o Izaaku, wspomina też o jego nadzwyczajnej ascezie i daleko idącej powściągliwości w przyjmowaniu pokarmów, gdyż ,zjadał tylko trzy kromki chleba na tydzień, a do tego nieco jarzyn".

18 Por. J.B. Chabot, Synodicon Orientale ou Recueil des Synodes nestoriens, w: „Notices et Exstraits des Manuscrits de la Bibliothèque Nationale" 37 (1902) 216 (textus), 482 (versio).

19 Por. Hryniewicz, Nadzieja świętych - świadectwo św. Izaaka Syryjczyka, s. 149.

${ }^{20}$ Por. Rejak, Eschatologiczna nadzieja, s. 16, przypis 12.

21 Por. Hieronymus, De viris illustribus 109, PL 23, 705, tłum. SWP 125: „Dydym Aleksandryjski od dziecka pozbawiony był wzroku i dlatego nie umiał ani czytać, ani pisać. Dokonał jednak wobec wszystkich czynu godnego podziwu, opanowując nawet dialektykę i geometrię, nauki wymagające jak najbardziej władania oczyma. Napisał wiele wielkich dzieł". 
Pod koniec zaś swojego opowiadania o życiu Izaaka, autor ten dotyka jeszcze zagadnienia jego spuścizny literackiej. Wspomina o niej i historyk Iszodenah, lecz nie podaje konkretnej liczby pism ani ich tytułów, które wyszły spod pióra Izaaka. Natomiast ten anonimowy autor oznajmia, że Izaak „napisał pięć tomów, które do dziś są jeszcze znane, napełnionych słodką nauką" i na tym kończy swój przekaz. Również dzisiaj nie jesteśmy w stanie potwierdzić takiej liczby dzieł Izaaka ani podać ich tytułów. Na podstawie współczesnych badań możemy tylko stwierdzić, że i obecnie znane są tylko trzy tomy pism Izaaka ${ }^{22}$. Na zakończenie trudno też nie dostrzec, że anonim przemilcza spory wokół kontrowersyjnych idei teologicznych Izaaka, o których pisał Iszodenah ${ }^{23}$.

\section{3. Źródło wschodniosyryjskie anonimowego autora w języku arabskim.}

Obok dwóch wyżej wymienionych źródeł wypada jeszcze odnotować trzecie świadectwo, poświęcone Izaakowi Syryjczykowi: jest nim dokument wschodniosyryjski, zredagowany w języku arabskim. W biografii tej anonim nie podaje czasu życia i śmierci Izaaka, ani miejsca jego urodzenia.

Niektórzy jednak specjaliści, zajmujący się omawianym żywotem arabskim, starając się odpowiedzieć na pewne niewyjaśnione w nim pytania, stawiają mniej lub bardziej prawdopodobne hipotezy. Jedną z nich jest próba ustalenia miejscowości, w której Izaak przyszedł na świat. Na ten temat zabrał głos m.in. P. Wieliczkowskij we Wstępie do tłumaczonego przez siebie (po raz pierwszy) na język rosyjski pierwszego tomu z dzieł Izaaka Syryjczyka pt. Słowa duchowno-ascetyczne, opublikowanego w Moskwie w 1854 roku $^{24}$, wypowiadając się, że Izaak urodził się w Niniwie ${ }^{25}$. Taką samą informację znajdujemy w rosyjskim tłumaczeniu Dobrotolubije F. Zatwornika Wyszenskogo ${ }^{26}$. Tego samego zda-

22 Por. tom I: Mar Isaacus Ninevita, De perfectione religiosa, ed. P. Bedjan, Leipzig 1909; tom II: Sermones 1-2. Tekst tych Mów nie został jeszcze wydany (znajduje się on w rękopisach Bodleian syr.e. 7, Tehran, Issayi Collection, ms. 4 i nn); Sermo 3 (rozdziały o wiedzy): jej tekst nie jest jeszcze wydany (znajduje się w rękopisach Bodleian syr.e. 7. Tehran, Issayi Collection, ms. 4 i nn); Sermones 4-41: Isaac of Nineveh (Isaac the Syrian), ,The Second Part”, chapters IV-XLI, ed. S. Brock, CSCO 554, Scriptores syri 224, Louvain 1995; tom III: Sermones 1-17, Tekst nie wydany (znajduje się on w rękopisach Tehran, Issayi Collection, ms. 5); por. Алфеев, Духовный мир преподобного Исаака Сирина, s. 277.

${ }^{23}$ Rozdział ten został opracowany na podstawie wschodniosyryjskiego dokumentu zredagowanego przez nieznanego autora. Znajduje się on w: I.E. Rahmani, Studia Syriaca, I, Beiruth 1904, 33 (textus), 32 (versio).

${ }^{24}$ Por. Святого Отца нашего Исаака Сирина, епископа быввего ниневейского, „, Слова духовноподвижнечиские", переведены с греческого старцем Пасием Величковским, издание Козельской Введенской Оптиной Пустьни, Москва 1854.

25 Por. tamże, репринтное издоние: Свято-Введенская Оптина Пустынь 2004, s. XVII.

26 Pог. „Добротолюбие” в русском переводе, дополненное, иждевением Русского на Афон Пантелеймонова монастыря, t. 2, Москва 1884, репринтное издоние: Москва 1989. 689. 
nia jest i filaret F. Gumilewskij, założyciel rosyjskiej szkoły patrystycznej. W swoim podręczniku do patrologii pt. Historyczne nauczanie o Ojcach Kościoła, który ukazał się w serii: Święci Ojcowie i nauczyciele Kościoła w badaniach prawosławnych uczonych, nie pozostawia żadnej wątpliwości, że Niniwa była dla Izaaka Syryjczyka rodzinnym miastem ${ }^{27}$. Podobny punkt widzenia wyraził także krzewiciel antyku chrześcijańskiego w Rosji, J.M. Kosow, w książce Kościót Chrystusa ${ }^{28}$.

Kontynuując refleksję nad źródłem arabskim, trzeba przyznać, że zawiera ono wiele interesujących wiadomości, których nie ma u historyka Iszodenaha, biskupa Basry oraz w omawianym wyżej utworze zachodniosyryjskim. Wynika bowiem z niego, że Izaak wraz ze swoim rodzonym bratem, którego imienia nie znamy, wstąpił do wspólnoty mniszej Mar Mateusza. Na temat położenia geograficznego tej fundacji wypowiadał się m.in. S. Sobolewski, profesor Moskiewskiej Akademii Duchownej, a jednocześnie tłumacz drugiego przekładu pierwszego tomu pism Izaaka Syryjczyka na język rosyjski pt. Słowa ascetyczne, opublikowanego w 1911 r. w znanej Ławrze Siergiejew Psad ${ }^{29}$. Zdaniem Sobolewskiego, klasztor ten był położony niedaleko Niniwy ${ }^{30}$. Można przypuszczać, że na taką, a nie inną decyzję wyżej wymienionych autorów (Wieliczkowskij, Gumilewskij, Kosow), wskazujących na Niniwę, jako miejsce urodzenia Izaaka, mogła mieć wpływ bliska odległość dzieląca te dwa miejsca oraz późniejszy wybór Izaaka na biskupa tego miasta, chociaż nie potwierdza tego żadne dostępne i wiarygodne źródło.

Z dalszego opisu życia Izaaka w dokumencie arabskim dowiadujemy się, że Izaak wraz z bratem zaczęli się wyróżniać z grona pozostałych mieszkańców tego środowiska swoją wiedzą i ascetycznym trybem życia. Nic więc dziwnego, że wkrótce zaproponowano bratu Izaaka, by został przełożonym mnichów i podjął się ich kierownictwa. Natomiast Izaak ,po wypełnieniu monastycznego zwyczaju", czyli po nauczeniu się sztuki życia we wspólnocie, oddalił się na pustelnię do celi, która znajdowała się niedaleko tego domu mniszego, oraz całkowicie oddał się milczeniu i samotności, wyłączając się w ten sposób z ludzkiej społeczności. Brat Izaaka musiał być zaniepokojony tak radykalnym jego odosobnieniem, ponieważ często pisał do niego listy, w których usilnie prosił go o powrót do cenobium. Korespondencja ta, mimo odwoływania się do

27 Por. Ф. Гумилевский, Нсторическое учение об Отцах Церкви (Святые Отцы и учители Церкви в исследованях православньх ученьх), t. 3, Санкт-Петербург 1882, репринтное издоние: Москва 1996, 134.

${ }^{28}$ Рог. И.М. Косов, „Церковь Христова”, Мордовское книжное издательство, Саранск 1991, 220.

29 Pог. Иже во святьх Отиа нашего аввы Исаака Сирианина, „Слова подвижнеческие”, перевод Сергея Соболевского, Сергеев Посад 1911.

${ }^{30}$ Por. Иже во святьх Отиа нашего аввы Исаака Сирианина, „Слова подвижеческие, s. III, przypis 1. 
więzi rodzinnych i emocjonalnych, nie przyniosła oczekiwanego rezultatu, gdyż Izaak pozostał niezachwiany w swoim postanowieniu.

Nie cieszył się on jednak zbyt długo życiem eremickim, bowiem dalsze jego losy potoczyły się zupełnie inaczej niż tego sobie życzył. Otóż kiedy sława jego wiedzy i świętości rozeszła się wszędzie, został on wyniesiony do godności biskupiej miasta Niniwy. Warto w tym miejscu zauważyć, że zarówno przekaz arabski, jak i wschodniosyryjski Iszodenaha oraz zachodniosyryjski, wspominają o Izaaku, jako biskupie Niniwy. Jest to jeden z niewielu faktów z biografii Izaaka, o którym piszą jednocześnie trzej wymienieni hagiografowie. Jeśli zaś chodzi o przyczynę rezygnacji Izaaka z tego urzędu, to zachodzi już między nimi pewna różnica. Polega ona na tym, że biskup Basry tylko stwierdza, że Izaak uczynił to „,z przyczyny znanej Bogu”31, w dziele zaś zachodniosyryjskim jest wzmianka, zawierająca na ten temat nieco więcej informacji, gdyz jego autor podkreśla, iz Izaak uczynił to „, Z powodu błyskotliwości swego umysłu i swojej gorliwości”32. Powyższe dwie wypowiedzi są mimo wszystko bardzo ogólne i nie wyjaśniają jednoznacznie tej kwestii. Dopiero w dokumencie arabskim znajdujemy opis tego zdarzenia, który rzuca nowe światło na to zagadnienie. Jest w nim mowa o tym, że kiedy Izaak przebywał w swojej rezydencji, a było to w pierwszy dzień po jego konsekracji, przyszło do niego dwóch ludzi, z których jeden, jak się okazało, był bogaty i żądał od drugiego zwrócenia długu. Zamożny człowiek idąc na audiencję do swego pasterza, liczył zapewne na to, że biskup wystąpi zapewne w obronie cnoty sprawiedliwości i opowie się po jego stronie, jako osobie poszkodowanej w sporze. Można przypuszczać, że znana mu była łagodność i umiłowanie pokoju przez Izaaka i być może dlatego zastosował metodę pewnej presji psychicznej, by osiągnąć zamierzony cel, gdyż odezwał się do hierarchy słowami: „Jeśli ten człowiek odmawia zwrotu mojej własności, wtedy będę zmuszony podać go do sądu". Izaak zaś zaproponował swemu rozmówcy inną możliwość zażegnania tego konfliktu. Polegała ona na odwołaniu się do autorytetu tekstów natchnionych, jako ostatecznej instancji, co wyraził biskup Niniwy w słowach: „O ile święte Ewangelie uczą nas nie odbierać tego, co się daje, tobie należy dać temu człowiekowi co najmniej jeden dzień, żeby mógł oddać swój dług”. Niestety bogacz był tak wzburzony propozycją biskupa, iż doszło do tego, że nie panując nad sobą, wyrzekł w jego obecności takie zdanie: „Odłóż teraz na bok Ewangelie”. Zapewne Izaak wyniósł niemiłe wrażenie z przebiegu tego spotkania, a zwłaszcza był zaskoczony postawą i ostatnim stwierdzeniem chrześcijanina, gdyż sam tak zakończył dialog: „Jeśli tutaj nie liczą się z Ewangelią, to po co ja tu przyszedłem?". W dalszej części swego opowiadania autor dokumentu arab-

${ }^{31}$ Por. Chabot, Le livre de la chasteté, composé par Jésusdenah, évêque de Basrah, s. 63-64 n (textus), 53-54 n (versio), wyd. 2: Bedjan, Liber fundatorum monasteriorum, s. 508.

32 Por. I.E. Rahmani, Studia Syriaca, I, Beiruth 1904, 33 (textus), 32 (versio). 
skiego dodaje, że gdy Izaak spostrzegł, iż obowiązki pełnione przez hierarchę kościelnego nie odpowiadają jego skłonności do życia anachoreckiego, wówczas „święty zrzekł się biskupstwa i oddalił się na świętą pustynię Sketis”, gdzie pozostał do końca swego życia, osiągnąwszy wysoki stopień doskonałości ${ }^{33}$. Wydaje się jednak, że ten tak mało znaczący incydent nie mógł wpłynąć na tak radykalną decyzję Izaaka, iż opuścił biskupstwo Niniwy, lecz musiała mieć ona głębsze podłoże.

Podsumowując dotychczasowe rozważania dotyczące najstarszych źródeł o życiu Izaaka Syryjczyka, biskupa Niniwy, należy stwierdzić, że świadectwo wschodniosyryjskie Iszodenaha i zachodniosyryjskie, posiadają wiele wspólnych elementów, które się ze sobą pokrywają lub wzajemnie uzupełniają. Odnośnie zaś świadectwa wschodniosyryjskiego, zredagowanego w języku arabskim, trzeba zauważyć, że różni się ono w sposób zasadniczy od dwóch wyżej wymienionych. Ta rozbieżność między nimi jest czasami aż tak daleko idąca, że niekiedy ma się wrażenie, iż hagiografowie ci opowiadają o dwóch różnych osobach noszących to samo imię. Uwidacznia się to zwłaszcza w takich faktach, jak: miejsce jego urodzenia, konsekracji biskupiej, rozpoczęcia życia monastycznego po rezygnacji z tego urzędu i śmierci.

Na podstawie przedstawionych dwóch pierwszych źródeł, można wnioskować, że Izaak Syryjczyk żył w 2. poł. VII i na początku VIII wieku. Urodził się zaś w Beit Katraje, na zachodnim brzegu Zatoki Perskiej, o czym nas informują dwa żywoty. To właśnie tam w pobliżu morza Izaak spędził swoje dzieciństwo. Wspomina on o tym w swoich Mowach ascetycznych, w których znajdują się obrazy związane z tematyką morską. Można je dostrzec w Mowie 34 pod tytułem: „Tegoż błogosławionego Mar Izaaka. O pociechach, które miłosierny Bóg daje tym, którzy przybywają w milczeniu ze względu na Boga". W Mowie tej Izaak posługuje się obrazem nurka poszukującego pereł ukrytych w ostrygach. Zapewne widział więc w młodości cały złożony proces wydobywania ostryg, choć nie można wykluczyć, że i sam brał w nim udział, gdyż dobrze był zapoznany z tym rzemiosłem. Biskup Niniwy wylicza bowiem np. trudności związane z wydobywaniem ostryg na powierzchnię ziemi, do których m.in. należały wysokie fale morskie, niebezpieczeństwo wynikające z możliwości spotkania się z rekinami, czy też ryzyko narażenia życia z powodu dłuższego pobytu pod wodą. Nie ulega wątpliwości, że Izaak, jako mnich i mistyk, odznaczał się umiejętnością wykorzystywania obrazów morskich, by przy ich pomocy ukazać bogactwo oraz piękno życia duchowego. A oto Izaakowy opis trudności

${ }^{33}$ Opis tego wydarzenia por. J. Assemani, Bibliotheca Orientalis, I, Romae 1719, 445. 
wydobywania ostryg oraz jego symbolika zaczerpnięte z wyżej wymienionego dzieła Izaaka:

„Jeżeliby w każdej ostrydze nurek znajdował perłę, wówczas jakikolwiek człowiek szybko by się wzbogacił. Jeśliby nurek natychmiast wydobywał perłę, nie uderzałyby w niego fale i nie spotykałby się z rekinami, nie potrzebowałby wstrzymywać oddechu do tego stopnia, żeby prawie się dusił i nie byłby pozbawiony świeżego powietrza, które dostępne jest dla wszystkich i nie schodziłby w głębiny - wtedy częściej, niż uderza piorun i w obfitości trafiałyby się perły ${ }^{34}$. Tak chciej mnie zrozumieć. A ci, którzy zanurzają się w ocean milczenia, niech będą nauczycielami - ci którzy natrafiają na skarby w głębiach oceanu. Za ostrygi będziemy uważać modlitwy, na które napotyka rozum, a także kontemplację, przenikliwość, boskie poznanie, mądrość, duchową radość. Nurkowie bardzo często opuszczając się, znajdują zwykłe ciało (tzn. mięso ostrygi) i tylko niekiedy w jednej z nich przebywa perła" 35 .

Należy też zwrócić uwagę, że niektórzy autorzy zajmujący się biografią Izaaka Syryjczyka mylą go z Izaakiem z Amidy i z Izaakiem z Antiochii ${ }^{36}$. Wydaje się nam, że w trzech przedstawionych wyżej dokumentach, mimo zachodzących między nimi niezgodności, co do wielu zdarzeń, jest w nich mowa o jednej tylko postaci, a mianowicie o Izaaku Syryjczyku. Rzadko się bowiem zdarza - choć jest to niekiedy możliwe - by zaistniał taki zbieg okoliczności, w którym biskupami Niniwy zostaliby dwaj hierarchowie o tym samym imieniu, a po rezygnacji z tego urzędu, prowadziliby życie monastyczne.

${ }^{34}$ W czasach Izaaka rozpowszechniony był pogląd, zgodnie z którym perła pojawiała się w ostrydze w tym momencie, kiedy promień słońca lub piorun dostawały się do wnętrza ostrygi poprzez jej otwarte skorupki; por. Алфеев, Духовный мир преподобного Исаака Сирина, s. 253.

35 Por. Mar Isaacus Ninevita, Sermo 34, 4-6, CSCO 554, Syr 224, 134 i 136.

${ }^{36}$ Por. Starowieyski, SWPW 100. O Izaaku z Amidy i Izaaku z Antiochii pisze Gennadiusz, autor katalogu pisarzy, który jest kontynuacją De viris illustribus św. Hieronima, por. Gennadius Masiliensis, De viris illustribus 26 (Izaak z Amidy), PL 58, 1075B-1076A, SWP 208: „Izaak napisał O Trójcy Swiętej i $O$ Wcieleniu Pana dzieło bardzo trudne do zrozumienia i w sposób bardzo ciemny. Twierdzi, że w jednej naturze Bożej występują w ten sposób trzy osoby, że każda z osobna zachowuje coś sobie właściwego, czego nie ma druga. A więc Ojcu jest właściwe to, że sam bez początku jest początkiem innych, Synowi to, że zrodzony przez Ojca nie zaistniał później od Niego, a Duchowi Świętemu to, że nie jest ani stworzony, ani zrodzony, a jednak pochodzi od Syna”; tenże, De viris illustribus 67 (Izaak z Antiochii), PL 58, 1098B-1099A, SWP 208: „Izaak, kapłan Kościoła Antiocheńskiego, pisał w języku syryjskim przez długi okres czasu i wiele, ale szczególnie przeciw nestorianom i eutychianom. Pieśnią elegijną wyraził smutek z powodu zburzenia Antiochii (przez trzęsienie ziemi, 459 r.), śpiewając na tę samą nutę, co Efrem diakon nad upadkiem Nikomedii. Umiera za panowania Leona Maioriana (457-474)". 


\title{
LE PIÙ ANTICHE FONTI SULLA VITA DI ISACCO IL SIRO VESCOVO DI NINIVE
}

\author{
(Riassunto)
}

Due sono le notizie trasmesseci sulla vita di Isacco. L'una, detta siro-orientale, si legge al capitolo 124 del Liber castitatis o, secondo il titolo datogli da P. Bedjan, suo secondo editore, Libro dei fondatori di monasteri nel regno dei Persi e degli Arabi, scritto redatto probabilmente tra l'860 e l'870 da Isho'dnah, metropolita di Basra, o Bassora, nel sud dell'Iraq.

La seconda, quella siro-occidentale, è anonima, ed è stata pubblicata in una raccolta di Studia syriaca da I.E. Rahmani agli inizi del 900, prima di una serie di brevi profili di monaci nestoriani vissuti tra il VI e l'VIII secolo; essa procede forse da ambienti legati al convento di Rabban Shabur, nel Bet Huzaye, l'odierno Khuzistan iraniano, ove Isacco sembra aver passato gli ultimi anni della sua vita ed essere stato sepolto. Entrambe concordano in alcune poche informazioni, decisive per la sua biografia. Ci dicono che, originario del Bet Qatraye e ivi monaco, vi fu notato da Mar Giorgio, il cattolico, quando si recò in quella regione. Egli lo avrebbe allora portato con sé nel Bet Aramaye e qui, nel monastero di Bet'Awe, lo avrebbe consacrato vescovo di Ninive. Mar Giorgio fu cattolico della chiesa persiana tra il 661 e il 680/681. Di più: ci è possibile precisare la data del suo viaggio nel Bet Qatraye, grazie ai decreti del sinodo che lì presiedette, sottoscritti ,nel mese di "iyar del $57^{\circ}$ anno del regno degli Arabi", dunque nel maggio del 676. La vita di Isacco si situa così nella seconda metà del VII secolo.

Oltre a queste due fonti, di cui abbiamo già parlato, occorre sottolineare anche che abbiamo una terza testimonianza su Isacco il Siro: è un documento siro-orientale, scritto da un autore anonimo in lingua araba. Questo biografo non parla della nascita e della morte di Isacco, come anche del luogo della sua nascita. Questa fonte si trova in B. Assemani, presso la Bibliotheca Orientalis. In questa fonte araba ci sono molte informazioni interessanti, che non troviamo presso lo storico Isho'dnah, come anche in quella siro-occidentale. Da questo documento noi veniamo a sapere che Isacco insieme al proprio fratello entrò nel monastero di Mar Matteo. Dopo aver rinunciato al ministero di Vescovo di Ninive, Isacco si allontanò in Egitto, dove visse come eremita fino alla sua morte. 